\title{
Thermobaric Conditions at Ice-Water Interface in Subglacial Lake Vostok, East Antarctica
}

\author{
P. G. Talalay, A. N. Markov \\ Polar Research Center, Jilin University, Changchun, China \\ Email: ptalalay@yahoo.com
}

Received 28 April 2015; accepted 23 June 2015; published 29 June 2015

Copyright (C) 2015 by authors and Scientific Research Publishing Inc.

This work is licensed under the Creative Commons Attribution International License (CC BY). http://creativecommons.org/licenses/by/4.0/ c) (i) Open Access

\begin{abstract}
Thermobaric conditions of subglacial Antarctic environment remain poorly understood, despite recent advances in radar and seismic surveying. The direct accessing to the largest subglacial lake, Lake Vostok, was carried out twice by Russian scientists in February 2012 and January 2015, opening new opportunities for assessing the thermobaric conditions at ice-water interface. According to the assumption that ice sheet is "floating" on the lake, it was predicted that the water would rise $30-40 \mathrm{~m}$ in the bottom part of the borehole, but in fact the water rose from the lake to a height of more than $500 \mathrm{~m}$. To explain this phenomenon we assume that the pressure in Lake Vostok results from the external pressure of the entire mass of ice above it and the pressure of the water column that is overlaid above the point being considered. Extrapolation of temperature measurements from the deep bore-holes drilled at Vostok Station also confirmed that the bed of the ice sheet is at pressure melting point. As a result of accessing Lake Vostok, the pressure in the lake is reduced that would lead to the formation of a new additional layer of accretion ice on the lower ice sheet surface.
\end{abstract}

\section{Keywords}

Subglacial Lake, Ice Drilling, Hydrostatic Pressure, Borehole Temperature

\section{Introduction}

It is now generally recognized that a vast network of lakes, rivers, and streams exists thousands of meters beneath Antarctic Ice Sheet. As of 2010, 387 subglacial lakes have been identified; this will increase as surveys improve spatial coverage [1]. Prediction of the thermobaric conditions in Antarctic subglacial reservoirs is one 
of the most important challenges in relation to studies of gas hydrate formation, water circulation, unique habitat for life and accretion processes on the underside of the ice sheet. Estimation of the thermobaric conditions is especially important in a view of the ongoing projects to access and to directly sample subglacial lakes [2]-[4].

With dimensions of $280 \mathrm{~km}$ by $50 \mathrm{~km}$, Lake Vostok is largest subglacial lake in Antarctica. It is located under the similarly named Russian station, Vostok Station $\left(78^{\circ} 28^{\prime} \mathrm{S}, 106^{\circ} 48^{\prime} \mathrm{E}, 3488 \mathrm{~m}\right.$ a.s.l.) in the central part of East Antarctica (Figure 1). The area of Lake Vostok is about 15,790 km², and the thickness of the ice sheet in the region of Lake Vostok varies within 1950 - $4350 \mathrm{~m}$ [5]. The total ice volume above the lake without factoring in the islands is near $64,600 \mathrm{~km}^{3}$. True altitude of the ice-water interface relative mean sea level range from -600 $\mathrm{m}$ on the northern part to $-150 \mathrm{~m}$ in the southern part. Lake Vostok is at least $1000 \mathrm{~m}$ deep in the south and relatively shallow in the north and extreme southwest. The volume of water is about $6100 \mathrm{~km}^{3}$ and the average depth is about $400 \mathrm{~m}$. It has been shown that subglacial melting occurs in the north of Lake Vostok and freezing takes place in the south [6].

Drilling a deep Hole 5G started in February 1990 six years before the large subglacial lake under Vostok station was officially recognized [7]. Finally, after 22 years Russian team made contact with the Lake Vostok water February 5, 2012 at a depth $3769.3 \mathrm{~m}$ (Figure 2). The borehole liquid level rapidly raised, and visible outflow of drilling fluid form the mouth of the borehole was continued during $\sim 5$ min [8] [9]. The drill was immediately recovered, but upon reaching the surface the whole drill was filled and coated with refrozen water ice. It was predicted that the water would rise up the near-bottom part of the borehole, by $30-40 \mathrm{~m}$, but in fact the water rose far above. On January 2013, the drill deployment found the first signs of frozen lake water (cork of bright white hard material) at the depth of $3181.9 \mathrm{~m}$ at distance of $\sim 587 \mathrm{~m}$ from the bottom of ice sheet [10].

The frozen subglacial water was re-drilled and the first crescent-shaped fragments of frozen water ice were got from the depth of $3367 \mathrm{~m}$. At a depth of $3397 \mathrm{~m}$, the first "ice core" consisting of a white substance, clathrate hydrate mixture of lake gases and densifier, HCFC-141b, was retrieved. Deeper than $3406.1 \mathrm{~m}$ the drill began to recover the continuous full diameter core composed from outside frozen water ice and hydrate core. However, the Hole 5G-1 is inclined from the vertical by $\sim 6^{\circ}$, and during re-drilling the drill moved away from the axis of the main hole. That is why the crescent-shaped segment of glacial ice appeared in the core shortly after, and the proportion of glacial ice increased steadily with depth. Totally $34.1 \mathrm{~m}$ long core with frozen lake water was recovered.

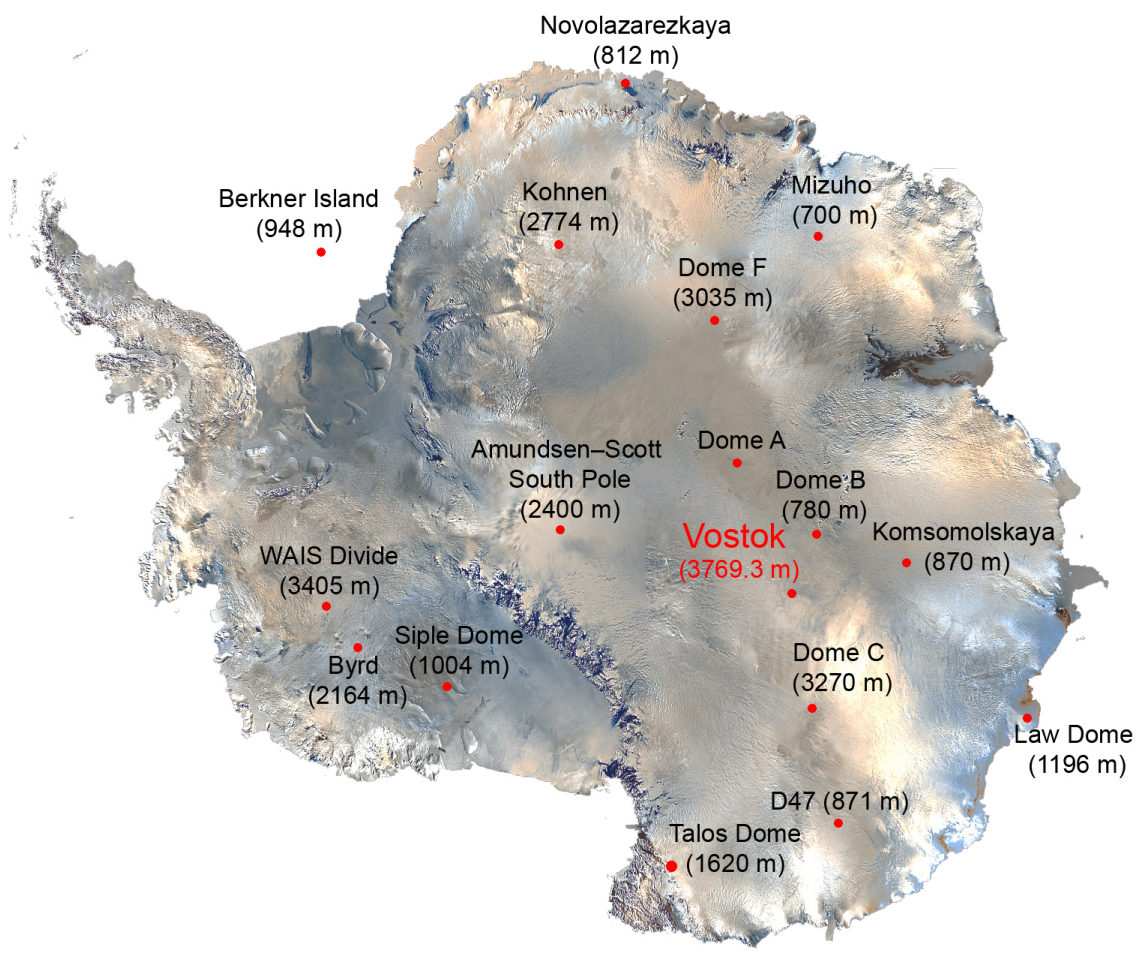

Figure 1. Vostok station and other deep ice coring sites on Antarctica. 

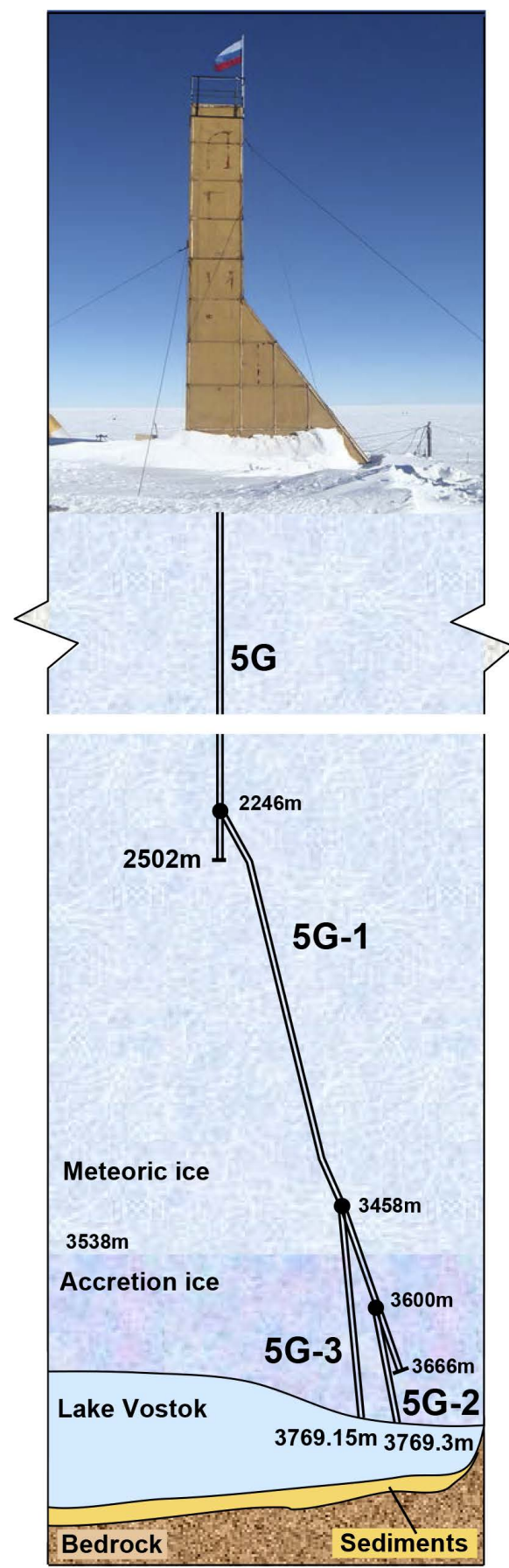

Figure 2. Schematic drawing of deep Hole 5G. Photo: G. Talalay (January, 2011).

Drilling was continued to the depth of $3765 \mathrm{~m}$ [11]. Then pressure logging of the hole revealed the underbalanced state of the drilling fluid column, and $800 \mathrm{~L}$ of densifier was added to the near-bottom part of the hole. Drilling was resumed, and on January 25, 2015 subglacial Lake Vostok was accessed for the second time at the depth of $3769.15 \mathrm{~m}$ (15 cm less than in 2012). Recovered drill was coated by frozen water almost in the same manner as after the first penetration. Before last run the liquid level was at the depth of $95.5 \mathrm{~m}$, but after pulling the drill level raised to $46 \mathrm{~m}$. Four days after penetration the drilling was again continued through fresh-frozen water starting from the depth of $3696.6 \mathrm{~m}$. It means that lake water raised to the height of $\sim 73 \mathrm{~m}$.

Clearly, the pressure in the Lake Vostok is much higher than expected. To explain this phenomenon we as- 
sume that the pressure in Lake Vostok results from the external pressure of the entire mass of ice above it and the pressure of the water column that is overlaid above the point being considered. The following considerations attempt to give explanations for uncontrolled blowout happened at Vostok Station.

\section{Pressure at Ice Sheet-Lake Vostok Interface}

According to available data [12] and its extrapolation, hydrostatic pressure of the drilling fluid column at the bottom of the Hole 5G-2 at the moment of the first accessing of Lake Vostok was equal to $33.515 \mathrm{MPa}$. The drilling fluid consisting of a mixture of kerosene and HCFC 141b, which is less dense than lake water, began to rapidly rise up the borehole. As a result, about $1.5-2.5 \mathrm{~m}^{3}$ of this fluid poured out through the mouth of the borehole to special trays, installed in the drilling building [8].

The Hole 5G and its upper part are practically vertical to the depth of $2400 \mathrm{~m}$, below this depth the angle is $6.3^{\circ} \pm 0.9^{\circ}$ [13]. It means that true vertical depth of the Hole $5 \mathrm{G}-2$ is $\sim 3761 \mathrm{~m}$ that can be taken as the ice thickness at Vostok station.

Surface topography above Lake Vostok, determined from satellite altimetry, showed that the ice surface above the Lake Vostok is very flat, an along-lake north-south slope is prominent, tilting $60 \mathrm{~m}$ over a horizontal distance of $\sim 250 \mathrm{~km}$ [14]. $90 \%$ of the surface of the ice-water contact can be approximated by a plane slightly inclined towards the north with an angle of not more than $0.1^{\circ}$ [5]. Simulations of ice sheet dynamics above Lake Vostok assumed that the overlying ice is in hydrostatic equilibrium [15] [16], and the ice/lake interface is considered to be a stress-free surface [17]. Thus, the shear stress in ice sheet due to surface slope is insignificant (less than $0.01 \mathrm{MPa}$ ).

The small amount of superincumbent under-stress ice is located in the down warping coastal area. The evaluation of the coastal topography shows that the south and west coastal area with length of coastal line of $\sim 200 \mathrm{~km}$ is inclined to the center of the lake at distance of $\sim 5 \mathrm{~km}$ with the angle $3.5^{\circ}$ and occupies an area of less than $6 \%$ of the entire surface of Lake Vostok. $4 \%$ of the lake surface, located along the northern part with length of coastal line of $\sim 75 \mathrm{~km}$, is inclined to the center of the lake at a distance of $\sim 9 \mathrm{~km}$ with an angle of $2^{\circ}$. Almost entire eastern of Lake Vostok has no up warping because the ice flow is beset by bedrock hillside. Therefore, we assume that the influence of shear stress in the coastal area of Lake Vostok on the vertical component of the gravity force of the whole ice mass is quite small and in a first approximation can be neglected.

In the assumption that the ice sheet is "floating" on the lake and is, hence, in hydrostatic equilibrium with the lake, the pressure on the ice-water interface was estimated to be equal to the local lithostatic pressure of the ice sheet at the point of drilling [18] [19]:

$$
P_{I}=\rho_{i} g\left(Z_{V}-z_{f}\right) \cdot 10^{-6} \approx 33.747 \mathrm{MPa},
$$

where $\rho_{i}$ is the average ice density, $\mathrm{kg} / \mathrm{m}^{3}$ (average ice density through the section vertically in the region of Vostok station can be taken equal to $923 \mathrm{~kg} / \mathrm{m}^{3}$ [20]); $g$ is the acceleration of gravity, $9.81 \mathrm{~m} / \mathrm{s}^{2} ; Z_{V}$ is the thickness of the ice sheet at Vostok station, $\mathrm{m} ; \mathrm{z}_{f}$ is the firn correction accounting for the air content in the upper snow-firn zone (for Vostok $z_{f}=34 \mathrm{~m}$ [21]).

According to this hypothesis the differential pressure, which is the difference between hydrostatic pressure of the drilling fluid in the borehole and the lake pressure, is approximately -0.231 MPa (Table 1), and the rise of the water level in the borehole would be $23.6 \mathrm{~m}$, which is far less than the observations. This means that the theoretical assumption that water in the Lake Vostok is equal to lithostatic pressure at the point of drilling is wrong.

Assuming Lake Vostok is totally isolated from the Antarctic subglacial drainage system, is sealed along its entire perimeter and forms a reservoir of water in which the pressure is hydrostatic. Then according to the Pascal's Law, full pressure $P$ at any point inside an isolated reservoir in homogenous field of the force of gravity consists from two components [22]:

$$
P_{I I}=P_{i}+P_{w},
$$

where $P_{i}$ is the external lithostatic pressure of ice sheet, MPa; $P_{w}$ is hydrostatic pressure of the water column, MPa.

External lithostatic pressure $P_{i}$ is determined by the integral of the total weight of superincumbent ice over the entire area of the lake (on Figure 3 the area between vertical lines $S$ and $N$ ). This pressure is uniform for any 
Table 1. Evaluation of pressure and temperature at ice-water interface in subglacial Lake Vostok and change of its condition after accessing.

\begin{tabular}{|c|c|c|c|}
\hline Parameters & Notation & Version I & Version II \\
\hline Lake pressure under Vostok Station, MPa & $P$ & 33.747 & 38.090 \\
\hline Differential pressure at the bottom of Hole 5G-2, MPa & $\Delta P$ & -0.231 & -4.574 \\
\hline Estimated rise of upwelling water in the borehole, $\mathrm{m}$ & - & 23.6 & 3883 \\
\hline Temperature at ice-water interface (pressure melting point), ${ }^{\circ} \mathrm{C}$ & $t_{m}$ & -2.68 & -3.06 \\
\hline Depth of pressure melting point due to extrapolation of temperature profile, m & - & 3776.7 & 3758.3 \\
\hline
\end{tabular}

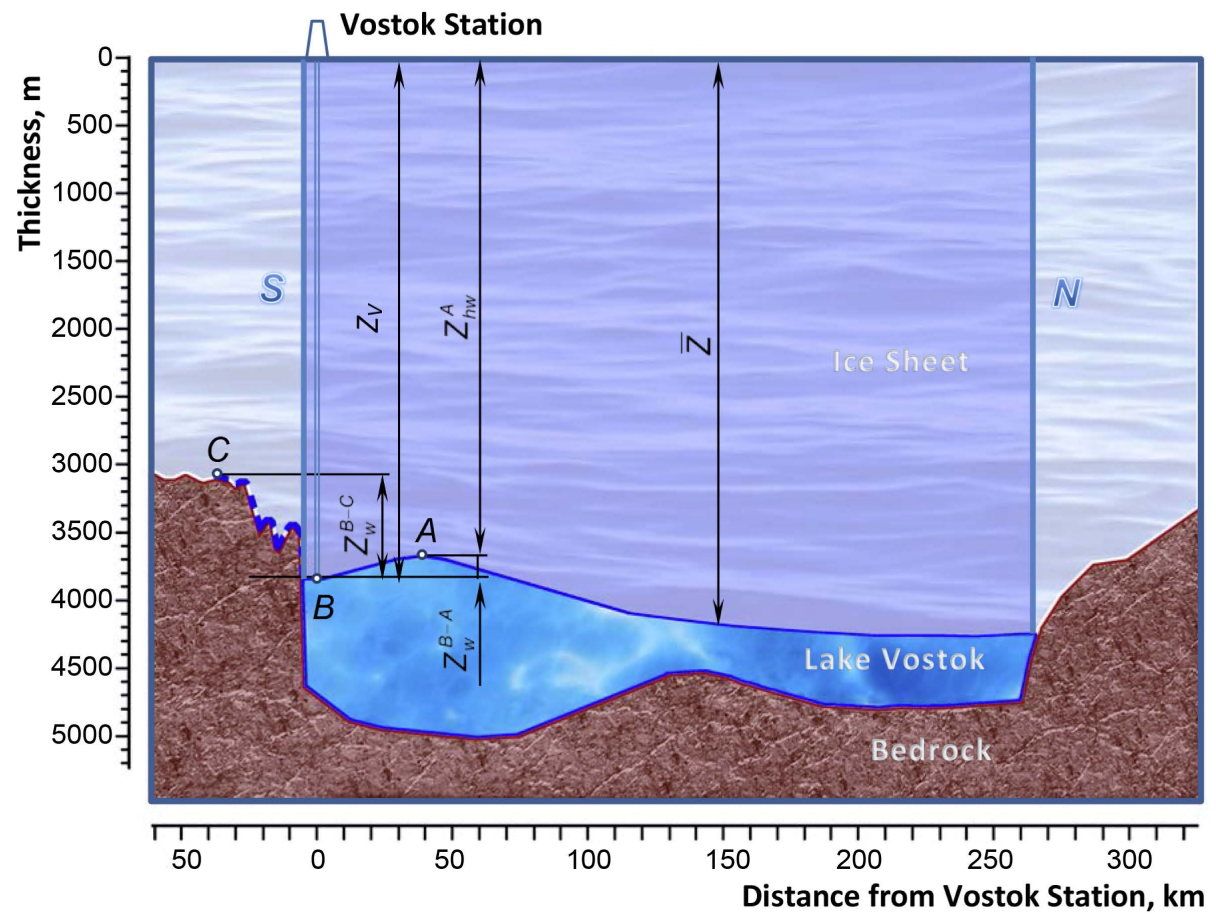

Figure 3. Schematic cross-section of Lake Vostok from south to north (using data from [5] [23]).

point at the ice-water interface and is determined with the equation:

$$
\begin{gathered}
P_{i}=\rho_{i} g \frac{V_{0}}{S_{0}} \cdot 10^{-6}, \text { or } \\
P_{i}=\rho_{i} g\left(\bar{Z}-z_{f}\right) \cdot 10^{-6},
\end{gathered}
$$

where $V_{0}$ is the entire ice volume above the lake's surface, $\mathrm{m}^{3} ; S_{0}$ is the horizontal area of the surface of ice-water interface, $\mathrm{m}^{2} ; \bar{Z}$ is the average ice thickness above subglacial lake, $\mathrm{m}$ (according to data published in [5] $\bar{Z}=4091 \mathrm{~m})$.

Hydrostatic pressure $P_{w}$ is created inside lake's volume by the action of gravity force of water column, the height of which is determined by the difference of height from the selected point to the point with maximum absolute altitude at the entire water-ice boundary:

$$
P_{w}=\rho_{w} g Z_{w} \cdot 10^{-6},
$$

where $\rho_{w}$ is the lake's water density, $\mathrm{kg} / \mathrm{m}^{3}, Z_{w}$ is the height of water column, $\mathrm{m}$.

The height of water-column $Z_{w}$ can be estimated according to ice thickness as following (Figure 4):

$$
Z_{w}=Z-Z_{h w} \pm \Delta H
$$




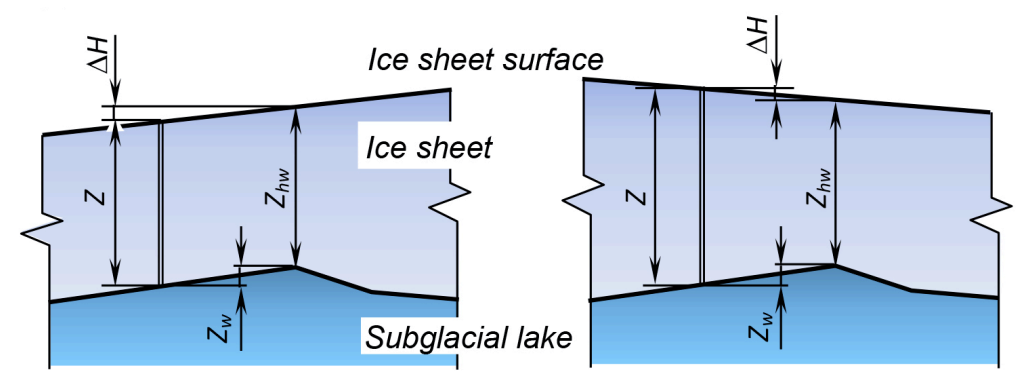

(a)

(b)

Figure 4. How to estimate height difference from the selected point to the point with maximum absolute altitude: (a) if surface of selected point is lower than high-water point; (b) if surface of selected point is higher than high-water point.

where $Z$ is the ice thickness at selected point, $\mathrm{m} ; Z_{h w}$ is the thickness of ice at the high-water point with maximum absolute altitude at the entire water-ice boundary, $\mathrm{m} ; \Delta H$ is the elevation difference between these points, $\mathrm{m}$.

The height of water-column between bottom of the hole 5G-2 and highest point of ice-water interface (height between points $B$ and $A$ on Figure 3 ) is estimated due:

$$
Z_{w}^{B-A}=Z_{V}-Z_{h w}^{A}-\Delta H^{B-A} \approx 138 \mathrm{~m},
$$

where $Z_{h w}^{A}$ is the minimal ice thickness above Lake Vostok (3600 $\mathrm{m}[5]$ ); $\Delta H^{B-A}$ is the altitude different between Vostok station and ice sheet surface with minimal ice thickness $\left(\Delta H^{B-A}=3488-3465=23 \mathrm{~m}\right)$.

So, assuming that the pressure in the Lake Vostok is composed of the external pressure of the entire mass of ice above the lake and the pressure of the water column that is overlaid above the point being considered, we obtain:

$$
P_{I I}=\rho_{i} g\left(\bar{Z}-z_{f}\right) \cdot 10^{-6}+\rho_{w} g Z_{w}^{B-A} \cdot 10^{-6} \approx 38.09 \mathrm{MPa} .
$$

In this case, the rise of water level in the borehole is greater than the $3761 \mathrm{~m}$ vertical height of the Hole $5 \mathrm{G}-2$. This means that even if the entire borehole is filled with subglacial water, the excessive pressure in the Lake Vostok would not be compensated, and the outflow of the water through the borehole mouth would continue like artesian well until the water freezes in the borehole. Such artesian supraglacial fountains are well known phenomenon and were observed in valley glaciers, e.g. at Trapridge Glacier, Yukon, Canada [24], John Evans Glacier, Ellesmere Island, Canada [25], Vatnajökull Ice Cap [26] and others. We assume that the upwelling of subglacial water at Vostok Station in the Hole 5G has stopped not due to equalization of the pressure in the lake and drilling fluid, but because of freezing of the lake's water in the hydraulic fracturing cracks between borehole bottom and lake.

There is good reason to believe that the real interface between the ice sheet and the subglacial water lies a few meters below the bottom of the hole, and that lake water rose into the hole through intergranular cracks formed secondary to the large pressure difference between the lake and the fluid in the borehole. This phenomenon is widely known in geology and mining as fracturing, and it occurred in Greenland in 2004, when subglacial water rose into the hole although the ice sheet bed was about $6 \mathrm{~m}$ beyond the bottom of the borehole [27]. During the Antarctic summer season of 2006-2007, in a deep borehole at the Dome Fuji Station, subglacial water began to leak into the borehole a few meters above the ice sheet bed [28].

Radar profiling has recorded a chain of subglacial water layers at $30 \mathrm{~km}$ west of the Vostok Station with elevations that are up to $850 \mathrm{~m}$ higher than the edge of the Lake Vostok (point $C$ on Figure 3 [23]). It could be speculated that this subglacial aquatic system is interconnected and includes Lake Vostok. It is quite probable that the connecting channels are not detected by the radar due to complex surface relief or as a result of their small thickness. If so, the pressure at the ice-water interface should be much higher as has been noted above.

When a subglacial lake is accessed by a borehole with negative differential pressure, the pressure in the lake is reduced to some extent, and as a result the accretion ice would be formed at least in the area around the bottom of the drill-hole. In this way, the accessing of subglacial lake would lead to significant change of the system's condition, which has existed for hundreds of thousands of years without external influences. 


\section{Temperature at the Ice-Water Interface}

Temperature measurements in deep boreholes at Vostok Station were regularly carried out since beginning of 1970-s [13] [29] [30]. R.N. Vostretsov (personal communication, 1999) compared data obtained in different expeditions and in different holes drilled at Vostok Station and tabulated the summary sheet. Fitting a polynomial to these data gives the following approximation for temperature profile at Vostok Station in the lower part of the ice sheet at depths range from 1806 to $3606 \mathrm{~m}$ :

$$
t=-48.832-5.9529 \times 10^{-3} Z+7.4421 \times 10^{-6} Z^{2}-6.965 \times 10^{-10} Z^{3} .
$$

This equation gives the opportunity to predict the temperature at the bed of ice sheet taking into account the temperature of the ice-water interface which is equal to the pressure melting point. As the pressure $P$ [in $\mathrm{MPa}$ ] increases, the melting temperature $t_{m}[\mathrm{in} \mathrm{K}]$ of ice decreases as follows (modified from [31]):

$$
P=611.66 \times 10^{-6}\left\{1+\sum_{i=1}^{3} a_{i}\left[1-\left(\frac{t_{m}}{273.16}\right)^{b_{i}}\right]\right\} .
$$

Using the pressure from Equation (8), ice temperature at the bed of the sheet would be equal to $-3.06^{\circ} \mathrm{C}$. Extrapolation and solving of Equation (9), gives the depth of $3758.3 \mathrm{~m}$ at pressure melting that is in close proximity to the true vertical depth of Lake Vostok accessing ( 3761 m).

The temperature gradient up to the depth of $2500 \mathrm{~m}$ is close to linear, and in lower part of the ice sheet it decreases to $0.02206^{\circ} \mathrm{C} / \mathrm{m}$ as the ice-water interface is approached (Figure 5). Extrapolation of temperature measurements below $3606 \mathrm{~m}$ gives estimates of geothermal heat flux at the ice sheet base as $46.2 \mathrm{~mW} \cdot \mathrm{m}^{-2}$ that is lower than it was obtained by modeling [32].

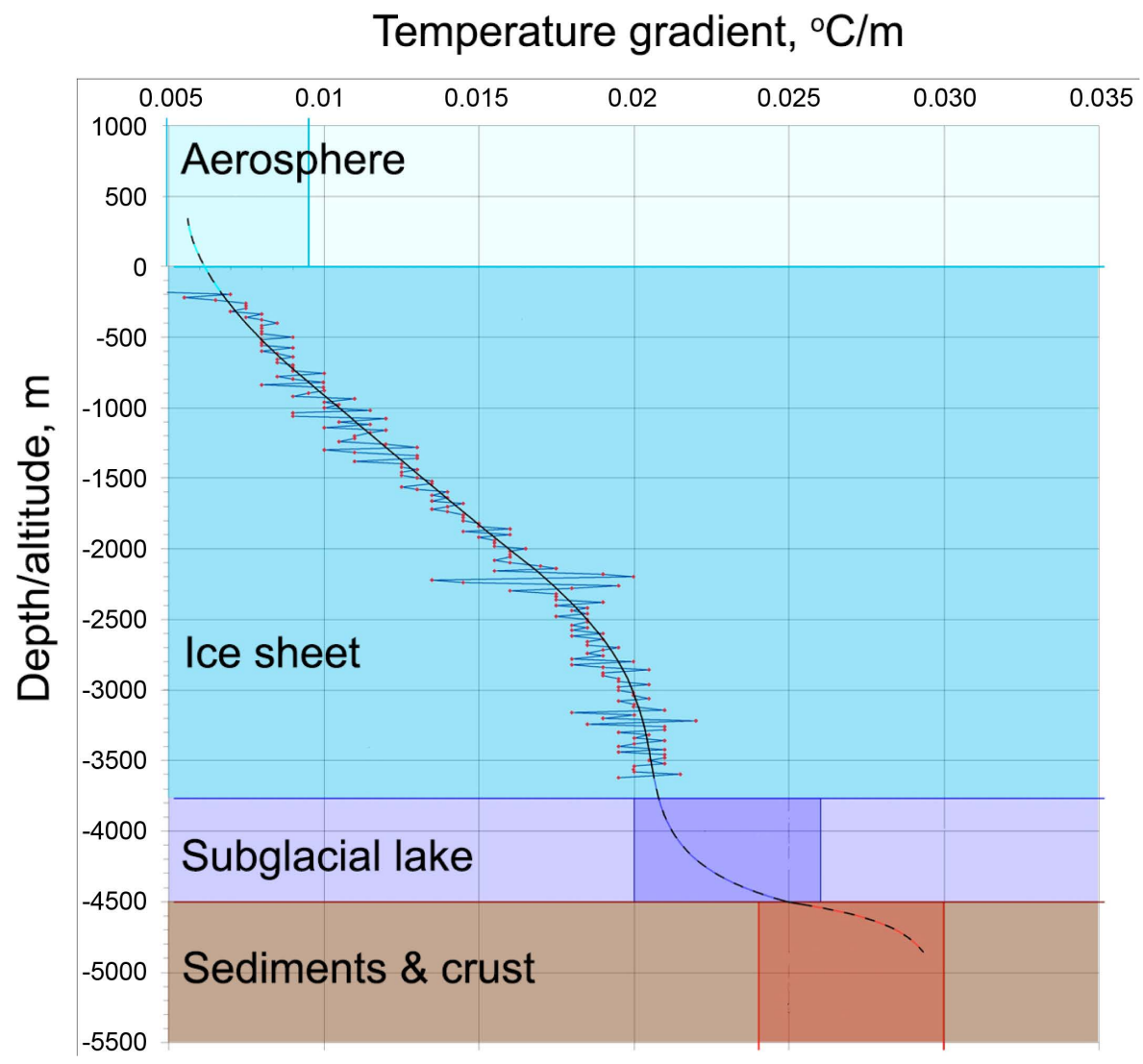

Figure 5. Measured temperature gradient in ice sheet at Vostok Station revealed from deep bore holes and predicted temperature gradient in air, subglacial Lake Vostok, sediments and Earth's crust within allowable limits (marked by more dark color). 


\section{Conclusions}

The estimation of the pressure at ice-water interface in isolated subglacial reservoirs being equal to the local lithostatic pressure of the ice at the drilling point does not account the hydrostatic features of subglacial environment. Repercussion of Lake Vostok showed that the pressure difference between hydrostatic pressure of drilling fluid and lake pressure was incorrectly calculated, and the pressure in the Lake Vostok is much higher than expected. Perhaps, the assumption that the ice sheet is simply "floating" on the lake, is only appropriate for active subglacial lakes which are draining into other lakes or into isolated pathways that connect to the ocean [33] or a few ice thickness away from grounded lake margins.

Our most probable scenario assumes that the pressure in this totally isolated reservoir which has a complex ice-water interface, results from the external pressure of the entire mass of ice above it and the pressure of the water column that is overlaid above the point being considered. It is possible that rising subglacial water rising into the borehole could, and, outflows through the mouth similar to artesian aquifer flow if the borehole does not freeze closed.

When Lake Vostok was accessed by a borehole with negative differential pressure, subglacial water inevitably upwells into the borehole and the condition of thermobaric equilibrium is disturbed to some extent. At this point thermobaric conditions in the lake changed, leading to the freezing-on of additional accreted ice to the ice sheet base. These assumptions should be considered for future subglacial lakes exploration.

\section{Acknowledgements}

This paper describes the research done under support of the National Science Foundation of China (Projects No. 41276189 and No. 41327804), Geological Survey of China (Project No. 3R212W324424) and Ministry of Land and Resources of China (Project No. 201311041). The authors thank R.N. Vostretsov (St.-Petersburg Sated Mining University, passed away in October 2002) and S.V. Popov (Polar Marine Geological Expedition, St.Petersburg) for provided data and V. N. Golubev (Research Laboratory of Avalanches and Landslides, Geographical Faculty, Moscow State University) for very constructive and pertinent remarks. The author also thanks K. Makinson (British Antarctic Survey) for healthy criticism and editing of this paper.

\section{References}

[1] Wright, A. and Siegert, M.J. (2011) The Identification and Physiographical Setting of Antarctic Subglacial Lakes: An Update Based on Recent Discoveries. In: Siegert, M.J., Kennicutt II, M.C. and Bindschadler, R.A., Eds., Antarctic Subglacial Aquatic Environments, Geophysical Monograph Series, 192, 1-7.

[2] Fricker, H.A., Powell, R., Priscu, J., Tulaczyk, S., Anandakrishnan, S., Christner, B., Fisher, A.T., Holland, D., Horgan, H., Jacobel, R., Mikucki, J., Mitchell, A., Scherer, R. and Severinghaus, J. (2011) Siple Coast Subglacial Aquatic Environments: The Whillans Ice Stream Subglacial Access Research Drilling Project. In: Siegert, M.J., Kennicutt II, M.C. and Bindschadler, R.A., Eds., Antarctic Subglacial Aquatic Environments, Geophysical Monograph Series, 192, 199219.

[3] Lukin, V. and Bulat, S. (2011) Vostok Subglacial Lake: Details of Russian Plans/Activities for Drilling and Sampling. In: Siegert, M.J., Kennicutt II, M.C. and Bindschadler, R.A., Eds., Antarctic Subglacial Aquatic Environments, Geophysical Monograph Series, 192, 187-197.

[4] Mowlem, M.C., Tsaloglou, M.-N., Waugh, E.M., Floquet, C,F.A., Saw, K., Fowler, L., Brown, R., Pearce, D., Wyatt, J.B., Beaton, A.D., Brito, M.P., Hodgson, D.A., Griffiths, G., Bentley, M., Blake, D., Capper, L., Clarke, R., Cockell, C., Corr, H., Harris, W., Hill, C., Hindmarsh, R., King, E., Lamb, H., Maher, B., Makinson, K., Parnell, J., Priscu, J., Rivera, A., Ross, N., Siegert, M.J., Smith, A., Tait, A., Tranter, M., Wadham, J., Whalley, B. and Woodward, J. (2011) Probe Technology for the Direct Measurement and Sampling of Ellsworth Subglacial Lake. In: Siegert, M.J., Kennicutt II, M.C. and Bindschadler, R.A., Eds., Antarctic Subglacial Aquatic Environments, Geophysical Monograph Series, 192, 159-186. http://dx.doi.org/10.1029/2010gm001013

[5] Popov, S.V., Masolov, V.N. and Lukin, V.V. (2011) Ozero Vostok, Vostochnaya Antarctida: Moschnost’ lednika, glubina ozera, podlyednyi i korennoi relyef [Lake Vostok, East Antarctica: Thickness of Ice, Depth of the Lake, Subglacial and Bedrock Topography]. Snegilyed [Snow and Ice], 1, 25-35. [In Russian]

[6] Siegert, M. J., Kwok, R., Mayer, C. and Hubbard, B. (2000) Water Exchange between the Subglacial Lake Vostok and the Overlying Ice Sheet. Nature, 403, 643-646. http://dx.doi.org/10.1038/35001049

[7] Kapitsa, A.P., Ridley, J.K., de Robin, Q.G., Siegert, M.J. and Zotikov, I.A. (1996) A Large Deep Freshwater Lake beneath the Ice of Central East Antarctica. Nature, 381, 684-686. http://dx.doi.org/10.1038/381684a0 
[8] Vasiliev, N.I., Lipenkov, V.Ya., Dmitriev, A.N., Podolyak, A.V. and Zubkov, V.M. (2012) Rezul'taty i osobennosti bureniya skvazhiny 5G i pervogo vskrytiya ozera Vostok [Results and Characteristics of 5G Hole Drilling and the First Tapping of Lake Vostok]. Snegilyed [Snow and Ice], 4, 12-20. [in Russian].

[9] Talalay, P.G. (2012) Russian Researchers Reached Subglacial Lake Vostok in Antarctica. Advances in Polar Science, 23, 176-180. http://dx.doi.org/10.3724/SP.J.1085.2012.00176

[10] Lukin, V.V. and Vasiliev, N.I. (2014) Technological Aspects of the Final Phase of Drilling Borehole 5G and Unsealing Vostok Subglacial Lake, East Antarctica. Annals of Glaciology, 55, 83-89. http://dx.doi.org/10.3189/2014AoG65A002

[11] Lukin, V.V. (2015) Novyi shag k neizvedannomu (k proniknoveniyu v podlednikovoe ozero Vostok 25 yanvarya 2015 g.) [A New Step into the Unknown (About Penetration into the Subglacial Lake Vostok on January 25, 2015)]. AARI Press. http://www.aari.nw.ru/news/text/2015/Восток 2015.pdf (In Russian)

[12] Lukin, V.V. (2011) Poslednie shagi pered nachalom proniknoveniya v ozero Vostok (The Last Steps before the Penetration into Lake Vostok). Press Release of Arctic and Antarctic Research Institute, St-Petersburg. www.aari.nw.ru/docs/press_release/2011/Восток 1412 add.pdf (In Russian)

[13] Salamatin, A.N., Vostretsov, R.N., Petit, J.-R., Lipenkov, V.Y. and Barkov, N.I. (1998) Geofizicheskiye i paleklimaticheskiye prilozheniya sostavnogo temperaturnogo profilya iz glubokoi skvazhyni na stantsii Vostok (Antarcktida) [Geophysical and Paleoclimatic Implications of the Stacked Profile from the Deep Borehole at Vostok Station (Antarctica)]. Materialy gliatsiologicheskikh issledovanii (Data of Glaciological Studies), 85, 233-240. (In Russian)

[14] Liu, H., Jezek, K.C. and Li, B. (1999) Development of an Antarctic Digital Elevation Model by Integrating Cartographic and Remotely Sensed Data: A Geographic Information System Based Approach. Journal of Geophysical Research, 104, 23199-23213. http://dx.doi.org/10.1029/1999jb900224

[15] Siegert, M.J., Ellis-Evans, J.C., Tranter, M., Mayer, C., Petit, J.-R., Salamatin, A. and Priscu J.C. (2001) Physical, Chemical and Biological Processes in Lake Vostok and Other Antarctic Subglacial Lakes. Nature, 414, 603-609. http://dx.doi.org/10.1038/414603a

[16] Popov, S.S., Sheremetyev, A.N., Masolov, V.N. and Lukin, V.V. (2005) Beregovaya cherta podlenikovogo ozera Vostok i prilegayuchshie vodoemy: Interpretatsiya dannykh radiolokatsionnogo profilirovaniya (The Coastal Feature of Subglacial Lake Vostok and the Surrounding Reservoirs: Interpretation of Radar Sounding). Data of Glaciological Research, 98, 73-80. (In Russian)

[17] Pattyn, F., De Smedt, B. and Souchez, R. (2004) Influence of Subglacial Vostok Lake on the Regional Ice Dynamics of the Antarctic Ice Sheet: A Model Study. Journal of Glaciology, 50, 583-589. http://dx.doi.org/10.3189/172756504781829765

[18] Verkulich, S.R., Kudryashov, B.B., Barkov, N.I., Vasiliev, N.I., Vostretsov, R.N., Dmitriev, A.N., Zubkov, V.M., Krasilev, A.V., Talalay, P.G., Lipenkov, V.Y., Savatyugin, L.M. and Kuz’mina, I.N. (2002) Proposal for Penetration and Exploration of Sub-Glacial Lake Vostok, Antarctica. Memoirs of National Institute of Polar Research, 56, 245-252.

[19] Water Sampling of the Subglacial Lake Vostok (2002) Draft Comprehensive Environmental Evaluation, XXV Antarctic Treaty Consultative Meeting, Working Paper WP-019, Agenda Item: CEP 4c.

[20] Salamatin, A.N., Lipenkov, V., Smirnov, Y., Ye, K. and Zhilova, Y.V. (1985) Plotnost' Iednikovogo I'da i yego reologicheskiye svoystva (The Density of Glacier Ice and Its Rheological Properties). Antarktika, 24, 94-106. (In Russian)

[21] Tchistyakov, V.K., Kracilev, A., Lipenkov, V.Y., Balestrieri, J.P., Rado, C. and Petit, J.R. (1994) Behavior of a Deep Hole Drilled in Ice at Vostok Station. Memoirs of National Institute of Polar Research, 49, 247-255.

[22] Markov, A.N. and Talalay, P.G. (2014) Otsenka termobaricheskogo sostoyania i izmenenia balansa massy podlednikovogo ozera Vostok posle vsrytia (Assessment of Thermobaric State and Change of the Mass Balance in the Subglacial Lake Vostok after Drilling-In). Lied iSneg (Ice and Snow), 1, 20-26. (In Russian)

[23] Popov, S.V. and Chernoglazov, Y.B. (2011) Podlednikovoe ozero Vostok, Vostochnaiya Antarktida: Beregovaiy liniya i okrujayuhie vodoyomi (Subglacial Lake Vostok, East Antarctica: The Coastline and Surrounding Waters). Snegilyed (Ice and Snow), 1, 13-24. (In Russian)

[24] Flowers, G.E. and Clarke, G.K.C. (2002) A Multicomponent Coupled Model of Glacier Hydrology 2. Application to Trapridge Glacier, Yukon, Canada. Journal of Geophysical Research, 107, 2288. http://dx.doi.org/10.1029/2001JB001124

[25] Copland, L., Sharp, M.J. and Nienow, P.W. (2003) Links between Short-Term Velocity Variations and the Subglacial Hydrology of a Predominantly Cold Polythermal Glacier. Journal of Glaciology, 49, 337-348. http://dx.doi.org/10.3189/172756503781830656

[26] Flowers, G.E., Björnsson, H., Pálsson, F. and Clarke, G.K.C. (2004) A Coupled Sheet-Conduit Mechanism for Jökulhlaup Propagation. Geophysical Research Letters, 31, Article ID: L05401. http://dx.doi.org/10.1029/2003GL019088

[27] Johnsen, S.J., Hansen, S.B., Sheldon, S.G., Dahl-Jensen, D., Steffensen, J.P., Augustin, L., Journé, P., Alemany, O., Rufli, H., Schwander, J., Azuma, N., Motoyama, H., Popp, T., Talalay, P., Thorsteinsson, T., Wilhelms, F. and Zago- 
rodnov, V. (2007) The Hans Tausen Drill: Design, Performance, Further Developments and Some Lessons Learned. Annals of Glaciology, 47, 89-98. http://dx.doi.org/10.3189/172756407786857686

[28] Motoyama, H. (2007) The Second Deep Ice Coring Project at Dome Fuji, Antarctica. Scientific Drilling, 5, 41-43. http://dx.doi.org/10.5194/sd-5-41-2007

[29] Vostretsov, R.N., Dmitriev, D.N., Putikov, O.F., Blinov, K.V. and Mitin, S.V. (1984) Osnovnyie rezul'taty geofizicheskih issledovanyi glubokikh svazhin i ledyanogo kerna v Vostochnoi Antarktide (The Main Results of Geophysical Studies of Deep Bore-Holes and Ice Core in East Antarctica). Materialy glyatsiologicheskikh issledovanyi (Data of Glaciological Studies), 51, 172-178. (In Russian)

[30] Markov, A.N. and Kotlyakov, V.M. (2006) Specific Features of the Ice Dynamics in Eastern Antarctica. Doklady Earth Sciences, 441, 1427-1430. http://dx.doi.org/10.1134/S1028334X06090200

[31] Wagner, W., Riethmann, T., Feistel, R. and Harvey, A.H. (2011) New Equations for the Sublimation Pressure and Melting Pressure of $\mathrm{H}_{2} \mathrm{O}$ Ice Ih. Journal of Physical and Chemical Reference Data, 40, Article ID: 043103. http://dx.doi.org/10.1063/1.3657937

[32] Pattynn, F. (2010) Antarctic Subglacial Conditions Inferred from a Hybrid Ice Sheet/Ice Stream Model. Earth and Planetary Science Letters, 295, 451-461. http://dx.doi.org/10.1016/j.epsl.2010.04.025

[33] Smith, B.E., Fricker, H.A., Joughin, I.R. and Tulaczyk, S. (2009) An Inventory of Active Subglacial Lakes in Antarctica Detected by ICESat (2003-2008). Journal of Glaciology, 55, 573-595. http://dx.doi.org/10.3189/002214309789470879 